УДК 004.89:316.42

DOI 10.35423/2078-8142.2021.1.1.03

С. В. Сидоренко, кандидат філософських наук, Запорізька обласна державна адміністращія, Департамент інформаційної діяльності та комунікацій з громадськістю, м. Запоріжжя, Україна e-mail: SvitlanaSidorenko312@gmail.com ORCID: http://orcid.og/0000-0002-4877-3518

\title{
ЦИФРОВА ТРАНСФОРМАЦІЯ СУСПІЛЬСТВА В УМОВАХ ЧЕТВЕРТОЇ ПРОМИСЛОВОЇ РЕВОЛЮЦІЇ
}

Актуальність обраної теми статті зумовлена глобалізаційними процесами у різних сферах суспільного буття, їх конвергениією, появою та розповсюдженням Інтернету у світі, який сприяв якісно новому етапу розвитку світу - загальної цифровізації економіки, політики, державного і муніципального управління, фiнансової сфери, освіти, культури, медицини та інших сфер життєдіяльності суспільства. «Цифрова трансформація» набула ознак четвертої промислової револющії. Технічні інновачії визначають темпи розвитку сучасного соиіуму. Цивілізаційні зміни у сфері циифровізації такі револючійні, глибинні, щчо світ не уявляється нам без Інтернету речей, роботизаиії, штучного інтелекту, створення великих даних, безпаперових технологій, 3D-друку, хмарного та туманного обчислення, безпілотних, мобільних, біометричних технологій тощзо. Сучасні циивілізачійно-технологічні зміни формують певні особливості філогенетичного розвитку людини: по-перше, розвиток техніки спричиняе зміни у свідомості людини, «формується» «иифрова людина»- Hото digitalis, з іншим мисленням, світоглядом, доступом до знань у режимі реального часу, яка завдяки штучному інтелекту і робототехніки реалізує та вирімує значно складніші економічні, управлінські, освітні, естетичні, елітарні, творчі проєкти та задачі, змінюючи аксіологічні ос-

(C) Сидоренко С. В., 2021 
ISSN 2078-8142 Multiversum. Philosophical almanac. 2021. Issue 1(173). Vol. 1.

нови буття. По-друге, у иифровому бутті людина не лище отримує нові можливості для творчості, а й стикається із загрозами власного існування, зумовленими результатами ї̈ технікораціоналістичної діяльності, яка ігнорує буттєві основи людського роду та пропонує конструкиії особливого світу людини - штучної віртуальної реальності, втрачається міжособистісне пізнання. У цицфровому просторі людина є учасником усього того, щуо відбувається у технооб 'єднаному та взаємопов'язаному світі, створеному глобалізаційними процесами. Аналіз наукової літератури дає підстави стверджувати, щуо різні найактуальнімі аспекти глобалізації, ї̈ трансформацї та ролі людини в ній відобразилися у наукових статтях та монографіях украӥнських учених - В. Ляха, В. Воронкової, В. Лук'янець, О. Кравченко, Л. Озадовської, Р. Самчука, В. Пазенюка, К. Райди та ін., а також творів західних науковців, серед яких К. Шваб, К. Скіннер, Е. Гідденс, Д. Гелд, У. МакГрю, Д. Голдблатт, Д. Перратон, К. Робінсон, С. Грінгард, А. Прасад, М. Форд, К. Келлі, М. Фезерстоун, С. Леш, Р. Робертсон, Д. Стігліи, Ю. H. Xapapi ma ін.

Ключові слова: глобалізачія, циифрова людина, циифрове суспільство, циифровізація, циифрове буття, циифрова безбар'єрність, Інтернет речей, итучний інтелект, роботизація, дивергенція.

Глобалізація - це інтеграція, об'єднання всіх сфер суспільства у єдину економічну, політичну, соціальну, культурну систему. На думку В. Ляха, глобалізація не лише містить у собі економічні, технологічні чи фінансові складові, а й трансформує культуру, спосіб життя людей, систему цінностей і настанов, що визначають становище людини у світі [7, с. 95]. За словами Р. Самчука, за доволі короткий термін часу людство пройшло шлях від появи до зникнення «людини маси» чи «гвинтика» до людини «кочівника» чи «електронної людини» [11, с. 54].

Процеси глобалізації породжують невирішені глобальні проблеми. С. Кримський відзначав щодо цього: «Ми починаємо усвідомлювати, що людство опинилось у пастці власної могутності. Науково-технічний прогрес обернувся екологічною кризою, наслідки якої зараз важко прогнозувати. Могутній розвиток науки породив загрозу термоядерного знищення, антична любов до істини була скомпроментована цинізмом знання, що зоорієнтоване на ви- 
робництво зброї масового знищення, тобто позбуте моральних обріїв. І головне - буття як вищий дар долі перетворили в інструментальний засіб технічної стратегії людства, у предмет виробничої перебудови. Втрачається благоговіння перед існуючим, повага до нього і відповідальність за буття» [9, с. 182].

Глобальні проблеми, серед яких сьогодні, наприклад, пандемія COVID-19, об'єднали весь світ перед обличчям загрози. Так, на думку німецького економіста, засновника всесвітнього економічного форуму у Давосі, Клауса Шваба, світ вступив у четверту промислову революцію [16], а COVID-19 прискорив перехід до четвертої епохи промислової революції, тому потрібно створити такі умови, за яких нові технології у цифровому, біологічному, фізичному світі залишилися орієнтованими на людину та слугували суспільству. Експерти Всесвітнього економічного форуму вважають, що необхідно втілити концепцію «Великого перезавантаження» («The Great Reset») у життя. Вона $є$ тією силою, яка побудує та підживіть стійки, інклюзивні та справедливі економіки суспільств, що зможуть протистояти глобальній системній кризі. Економісти вважають, що її реалізація можлива також через використання інноваційних технологій четвертої промислової революції для підтримки суспільного блага. Крім цього, у квітні 2021 р. в Японії відбудеться віртуальна робоча зустріч, а саме - «Глобальний саміт управління технологіями», головними завданнями якої є адаптація економік країн до постпандемічного світу через цифрові технології. Умовою реалізації цього, передусім, є подолання джерел цифрової нерівності [6].

Аналізуючи сучасні тенденції цифрової трансформації суспільства в умовах четвертої промислової революції, Кріс Скіннер у монографії «Цифрова людина: четверта революція в історії людства, яка торкнеться кожного» розмірковує над тим, як людство пройшло три революції, які привели до цифрового суспільства. Перша революція - виникнення людства - від давніх гомінід до появи сучасної людини - Hото sapiens, яка пережила боротьбу за виживання. Друга революція - винахід грошей. Третя епоха - промислова революція 3 паровим двигуном, електрикою, комунікаціями. Масовий перехід від цехів до офісу ознаменував кінець промислової революції. Наприкінці XVII ст. одночасно втілилися в життя 
три найважливіші інновації: влада почала видавати банкам ліцензії на випуск банкнот і знімних записок, з'явилися чеки, а на зміну монетам і цінних товарів прийшли асигнації. Потім банківська система почала підживлювати промислову революцію, не лише забезпечуючи зручну торгівлю і обмін цінностями через паперові системи, а й підтримуючи структуру і функціонування фінансових систем в тому вигляді, в якому ми їх знаємо сьогодні. Четверта промислова революція - перехід від робототехніки до штучного інтелекту. На думку дослідника, її головною відмінністю $є$ те, що час і простір починають «стискатися», відстані скорочуються завдяки глобальним системам зв'язку. Кожен може укладати угоди, обмінюватися цифровими активами, спілкуватися і прицільно налагоджувати зв'язки у пірінговому режимі, або Р2Р-мережах [13, с. 27-41].

На думку білоруської дослідниці Г. Головєнчик, становлення та розвиток цифрових технологій формують нові функціональні види діяльності [3, с. 32]. Адже сучасна людина живе у взаємопов'язаному світі, в якому до Інтернету під'єднані комп'ютери, смартфони, термостати, відеокамери, полиці в супермаркетах, сенсори стану довкілля. За оцінками групи SiscoSystems, у світі є понад 1,5 трлн «речей» і згодом 99\% фізичних об’єктів стануть частиною мережі [5, с. 25].

Цифровізація - це, передусім, розробка, впровадження та розповсюдження новітніх цифрових технологій у всіх сферах буття сучасної людини в умовах глобалізації, які характеризується досягненнями Google, Amazon, Apple, IMB, Microsoft, Facebook у США, Alibaba i Tencent у Китаї.

Повсякденними стали такі категорії, як «цифрове місто». На думку багатьох філософів, поступово відбувається трансформація соціального простору у містах, конвергенція комп'ютерних та телекомунікаційних технологій з фотографіями, кіно, телебаченням. Таким чином, виникають нові засоби виробництва соціального простору, утворюються нові форми суспільної діяльності. Цифрові технології, засновані на програмному та апаратному забезпеченні, мережах, вдосконалюються, інтегруються та викликають трансформацію суспільства. Кевін Келлі у книзі «Невідворотне» описує, в 
який спосіб нові технології рухаються в бік масового поширення. Він вважає, що технології - це каталізатор людства, вони переживають постійну трансформацію, начебто відбувається «гонка озброєнь» у сфері їх оновлень. Машини переводять себе на наступний якісний рівень непомітно для нас і постійно змінюються 3 часом. Постійні оновлення перетворюють людину на «вічного навачка» - новий статус кожного за замовчуванням, незалежно від віку й досвіду. Технологічний імпульс підштовхує нас бігти за найновішим, а воно весь час зникає 3 появою наступного найновішого, тож задоволення раз-по-раз вислизає 3 наших рук [8, с. 1519].

Аналізуючи етапи розвитку глобалізації, науковець, економіст Р. Болдуїн пояснює передумови переходу до цифровізації. Ранні етапи розвитку суспільства підготували перехід до двох видів глобалізації, а саме - «Old globalization» та «New globalization», які, на його думку, різняться розподілом виробництва. Автор підкреслює, що вид «Old globalization» охоплює період з 1820 по 1990 pp. та характеризується дивергенцією доходів, швидким розвитком промислової революції та науковими винаходами. Наукова революція у 1990-ті роки у сфері інформаційно-комунікаційних технологій (ІКТ) змінила планетарну роль глобалізації. Так виникає другий вид глобалізації - «New globalization», зі швидкими темпами технологічних змін та фрагментацією виробництва, завдяки діяльності ТНК. Також крос-національною та міжнародною конкуренцією. В епоху «New globalization» виникають нові уявлення про соціальний простір, який об'єднує людей завдяки поступовому розвитку новітніх технологій. Актуальними тут є категорії «дистанційної присутності» - телеприсутності та дистанційної робототехніки (телероботіки). На думку автора, швидкий розвиток обчислювальної потужності і комунікаційних технологій зробить економічно вигідною віддалену роботу багатьох людей за кордоном. Telerobotics - це технологія, яка усуває поточну потребу у фізичному присутності на багатьох робочих місцях. Це роботи, якими керує не штучний інтелект, а людина [1].

На думку Н. Шаркі, професора Шефілдського університету, який досліджував проблеми штучного інтелекту і робототехніки, робототехніка переживає епоху розквіту. Завдяки появі великого 
міжнародного ринку держава й корпоративний світ почали всерйоз сприймати економічний потенціал роботів, а інвестиції у цю галузь поступово приносять реальну віддачу... Розвиток подій у галузі робототехніки залежатиме від міжнародної нормативної бази і від того, наскільки інженери-конструктори й фірми-виробники практикуватимуть соціально відповідальний підхід [17, с. 190].

Існують різноманітні точки зору щодо наслідків роботизації для суспільства. Так, оптимісти вважають, що роботам не під силу створювати прекрасне, закладене в кожному з нас від природи, адже, за словами С. Андроса, людина приходить у світ, щоб творити, створювати нові форми, примножувати розмаїття форм та проявів буття [4, с. 8]. А якщо припустити, що художників майбутнього автоматизують? Людина, вважають вчені, може стежити, щоб дії роботів не суперечили етиці. Кріс Скіннер вважає, що люди будуть обслуговувати людей, вони знадобляться, щоб ремонтувати роботів, люди будуть займатися підтримкою космічного туризму i забезпечувати людяність всієї системи. Для них з'являться нові спеціальності - дослідник даних, фахівець 3 доповненої психології, консультант і тренер з розробки автоматизованих сервісів.

За словами Ю.Н. Харарі, автора книги «21 урок для 21 століття», технологічні зрушення наберуть таких обертів, що поставлять людство перед найважчими випробуваннями: вони дадуть силу маніпулювати світом всередині нас, змінювати наші особистості, ментальну систему аж до іiі руйнації. Технологічна революція невдовзі може витіснити мільярди людей з ринку праці й створити величезний новий клас непотрібних, що призведе до таких соціальних і політичних заворушень, яких не зазнавала жодна 3 існуючих ідеологій [15, с. 24-37]. Погоджується 3 його думкою дослідниця В. Воронкова, яка підкреслює, що незважаючи на потенційний позитивний вплив інформаційних технологій на зростання економіки, не менш важливо врахувати їі можливі негативні наслідки для ринку праці. Поширення технологічного безробіття випереджає темпи, з якими ми знаходимо для вирішення цієї проблеми нове застосування, оскільки революція новітніх технологій призведе до глибших соціальних потрясінь, ніж попередні промислові революції [2, с. 32]. Шеллі Палмер, керівник консалтингової 
компаніï PalmerGroup, що працює у сфері технологій і бізнесу, вважає, що першою чергою роботи претендують на такі спеціальності: менеджери середньої ланки, продавці в роздрібній торгівлі, укладачі звітів, журналісти, автори і ведучі, бухгалтери і помічники бухгалтерів, лікарі, юристи. У звіті «Майбутнє робочих місць», представленому на Всесвітньому економічному форумі описується колосальна трансформація набору навичок і вмінь, необхідних для досягнення успіху в нових умовах: рішення складних проблем, критичне мислення, креативність, управління людьми, вміння координувати дії з іншими співробітниками, емоційний інтелект, здатність до суджень і вміння приймати рішення, орієнтованість на послуги, вміння домовлятися, когнітивна гнучкість [13]. Втрату багатьох традиційних робочих місць у всьому від мистецтва до охорони здоров'я частково компенсують нові робочі місця для людей [15, с. 50].

Разом зі світовими країнами Україна активно впроваджує політику цифровізації. 7 листопада 2018 набув чинності Закон України «Про електронні довірчі послуги». Метою цього закону є врегулювання відносин у сферах надання електронних довірчих послуг та електронної ідентифікації. Крім цього, створено Міністерство та Комітет цифрової трансформації України, однією з головних цілей якого є запровадження 100\% доступних публічних послуг для громадян та бізнесу до 2024 р. Так, у 2020 р. запрацювала концепція Президента України В. Зеленського «Держава в смартфоні». Понад 25 тисяч українців скористалося послугою «єМалятко». Система «Трембіта» дає можливість будувати безпечні інформаційні міжвідомчі взаємодії державним органам та органам місцевого самоврядування через інтернет шляхом обміну електронними повідомленнями між їх інформаційними системами. У 2020 р. розроблено каталог освітніх програм для вступників університетів з інформацією про підготовку фахівців у галузі штучного інтелекту (аналіз даних, машинне навчання, комп'ютерний зір, розпізнавання образів, обробка природної мови). Планується, що реалізація проєкту «Дія. Сity» забезпечить зростання IT-сектору на 40-50\% щороку.

У межах боротьби з пандемією COVID-19 на порталі «Дія» було відкрито онлайн послугу для громадян, де можна зареєстру- 
ватися у чергу очікування вакцинації. Міністерство цифрової трансформації розробило національний проєкт з цифрової грамотності українців «Дія. Цифрова освіта». У Концепції розвитку цифрових компетентностей, затвердженої Розпорядженням Кабінету Міністрів України від 3 березня 2021 р. №167-р., визначені пріоритетні напрями і основні завдання з питань розвитку цифрових навичок та цифрових компетентностей. Реалізація Концепції дасть змогу прискорити процеси цифрової трансформації в Україні; суттєво підвищити рівень цифрових навичок та цифрових компетентностей в суспільстві, а також рівень конкурентоспроможності держави та якість людського капіталу; підвищити конкурентоспроможність працівників шляхом оволодіння новими цифровими навичками та цифровими компетентностями; підвищити рівень доступності до державних послуг для громадян похилого віку, осіб з інвалідністю, малозабезпечених сімей, інших вразливих груп населення; суттєво зменшити ризики виникнення небезпек під час користування Інтернетом тощо.

У центрі уваги сучасних наукових досліджень залишається проблема цифрової грамотності населення України. Так, у Мінцифрі відзначають, що 15,1\% українців не володіють цифровими навичками, а $37,9 \%$ у віці $18-70$ років мають цифрові навички на рівні нижче середнього, 53\% знаходяться нижче позначки «середній рівень». Цифрова грамотність населення передбачає: вміння користуватися гаджетами, сформованою практикою «користування за аналогією», знання та вміння користуватись «безпечно» усіма гаджетами. Цифрова грамотність залежить від інфраструктурної складової (місцевості, наявності підготовлених кадрів, матеріально-технічної бази, наявності певної екосистеми з реалізації політики цифровізації населення), соціально-демографічних показників (вік, освіта, професійна зайнятість) [10]. Також, актуальною залишається проблема цифрової нерівності та безбар'єрності.

Робота щодо розвитку цифровізації в Україні триває, розвиток цифрової економіки та подолання цифрової нерівності залежить від розвитку інфраструктури, освіти та інформування населення. 


\section{ЛIТЕРАТУРА}

1. Ричард Болдуин. Великая конвергенция. Информационные технологии и новая глобализация. URL: https://www.hup.harvard.edu/ catalog.php?isbn $=9780674660489$ URL

2. Воронкова В. Г. Формування цифрових цінностей цифрового суспільства та суспільства четвертої промислової революції. Освіта як чинник формування креативних компетентностей в умовах цифрового суспільства. Матеріали Міжнародної науково-практичної конферениії 27-28 листопада 2019 р. Запоріжжя : ЗНУ, 2019. С. 32-37.

3. Головенчик Г. Г. Цифровая экономика как новый этап глобализации. Цифровая трансформация. 2018. № 1 (2). C. 26-36. URL: https:// core.ac.uk/download/pdf/231303806.pdf

4. Грані людського буття: позитивні та негативні виміри антропокультурного / Е. І. Андрос, Г. І. Шалашенко, В. П. Загороднюк, Н. В. Хамітов, А. М. Дондюк, Т. В. Лютий, Л. А. Солонько, Г. П. Ковадло, О. А. Ярош, К. С. Малєєв. К. : Науково-виробниче підприємство «Видавництво «Наукова думка» НАН України», 2010. 349 с.

5. Грінгард С. Інтеренет речей. Харків : Книжковий клуб «Клуб сімейного Дозвілля», 2018. 175 с.

6. The Great Reset. World Economic Forum. URL: https://www. weforum.org/great-reset

7. Інформаційне суспільство у соціально-філософській ретроспективі та перспективі / В. В. Лях, В. С. Пазенюк, Я. В. Любавий, К. Ю. Райда,В.К. Федорченко, О. М. Йосипенко, О. М. Соболь, Н. А. Фоменко, О. П. Будя, Ю. О. Безукладніков. Київ : ТОВ «ХХІ століття: діалог культур, 2009. $404 \mathrm{c}$.

8. Келлі К. Невідворотне. 12 технологій, що формують наше майбутнє. Київ : Наш формат, 2018. 304 с.

9. Кримський С. Запити філософських смислів. Київ : Вид. ПАРАПАН, 2003. $240 \mathrm{c}$.

10. Перше в історії України дослідження цифрової грамотності. URL: https://osvita.diia.gov.ua/uploads/0/585cifrova_gramotnist_naselenna_ ukraini_2019_compressed.pdf

11. Роуз Д. Дивовижні технології. Дизайн та інтернет речей. Харків : Книжковий Клуб «Клуб сімейного дозвілля», 2018. 336 с.

12. Самчук Р. Особистісне буття в умовах перманентних криз. Людина і культура. Острог : Вид-во НаУОА. С. 53-66. 
13. Скинер К. Цифровой человек. Четвертая революция в истории человечества, которая затронет каждого. Москва : Манн, Иванов и Фербер, 2019. $292 \mathrm{c}$.

14. Тегмарк М. Життя 3.0. Доба штучного інтелекту. Київ : Наш формат, 2019. $432 \mathrm{c}$.

15. Харарі Ювал Ной. 21 урок для 21 століття. Київ : Bookchef. 413 c.

16. Шваб К. Четвертая промышленная революція. URL: http://loveread.ec/read_book.php?id=66348\&p=1

17. Що далі? Все, що наука знає про наше майбутнє / ред. Дж. Аль-Халілі. Київ : Кі Фанд Медіа, 2018. 248 с.

\section{REFERENCES}

Baldwin, Richard. The Great Convergence. Information Technology and the New Globalization. Retrieved from https://www.hup.harvard.edu/catalog. php?isbn= 9780674660489 [In Russian].

Voronkova, V. (2019). Formation of digital values of digital society and society of the fourth industrial revolution. Education as a factor of formation of creative competences in the conditions of digital society. Proceedings of the International Scientific and Practical Conference November 27-28, Zaporizhzhia. ZNU, 32-37. [In Ukrainian].

Goloventchik, G. (2018). Digital economy as a new stage of globalization. Digital Transformation. 1. 26-36. Retrieved from https://dt.giac.by/ jour/article/view/61/53 [In Russian].

Andros, E., Shalashenko, G., Zagorodnyuk, V., Khamitov, N., Dondyuk, A., Liutyi, T.,... Maleev, K. (2010). Borders of the human being: positive and negative dimensions of the anthropocultural. Kyiv: Scientific Thought Publishing House of the National Academy of Sciences of Ukraine. [In Ukrainian].

Greengard, S. (2018). The Internet of Things. Kyiv: The MIT Press. [In Ukrainian].

The Great Reset. World Economic Forum. Retrieved from https://www. weforum.org/ great-reset [In Ukrainian].

Lyakh, V., Pazenyuk, V. and others. (2009). Information society in the social and the philosophical retrospective and perspective. Kyiv: Partnership «XXI centure: dialogue of cultures». [In Ukrainian]. 
Kelly, Kevin. (2018). The Inevitable. Understanding the 12 Technological Forces that will shape our future. Kyiv: Our format. [In Ukrainian].

Krymskiy, S. (2003). The requests of the philosophical meanings. Kyiv: PARAPAN. [In Ukrainian].

The first study of digital literacy in the history of Ukraine. Retrieved from https://osvita.diia.gov.ua/uploads/0/585cifrova_gramotnist_naselenna_ukraini_ 2019_compressed.pdf. [In Ukrainian].

Rose, D. (2018). Enchanted objects: design, human desire and the Internet of things. Kyiv: Family leisure club. [In Ukrainian].

Samchuk, R. (2019). Personal existence in conditions of permanent crises. Human and culture. Publishing house NauOA. Ostroh, 53-66. [In Ukrainian].

Skinner, C. (2019). Digital human. The force revolution of humanity includes everyone. Moscow: Mann, Ivanov and Ferber. [In Russian].

Tegmark, M. (2019). Being human in the age of artificial intelligence. Kyiv: Our format. [In Ukrainian].

Harari, Y. N. (2019). 21 Lessons for the 21st Century. Kyiv: Bookchef. [In Ukrainian].

Schwab, K. (2019). The Fourth Industrial Revolution. Retrieved from http://loveread.ec/read_book.php?id=66348\&p=1 [In Russian].

Al-Khalili, J. (Eds.). What next? (2018). Even scientists can't predict the future - or can they? Kyiv: Key Fund Media. [In Ukrainian].

\section{Svitlana Sydorenko}

Candidate of Philosophical Sciences (Ph.D.), Zaporizhzhia Regional State Administration, Department of Information Activities and Public Communications; Zaporizhzhia, Ukraine; e-mail: SvitlanaSydorenko312@gmail.com; ORCID: http://orcid.og/0000-0002-4877-3518

Digital transformation of society in the conditions of the fourth industrial revolution 


\section{Abstract}

The relevance of the chosen topic of the article is due to globalization processes in various spheres of society, their convergence, emergence and spread of the Internet in the world, which led to a qualitatively new stage of world development - comprehensive digitalization of economy, politics, public administration, finance, education, culture, medicine and other spheres of society. The «digital transformation» took on the characteristics of the fourth industrial revolution. Technical innovations determine the pace of development of modern society. Civilizational changes in the field of digitalization are so revolutionary, profound that the world cannot be imagined without the Internet of Things, robotics, artificial intelligence, big data creation, paperless technologies, 3D printing, cloud and fog computing, unmanned, mobile, biometric technologies and others. Modern civilization and technological changes form certain features of phylogenetic human development: first, the development of technology leads to changes in human consciousness, "formed» «digital human» - Homo digitalis, with a different mindset, worldview, access to real-time knowledge, which thanks to artificial intelligence and robotics implements and solves much more complex economic, managerial, educational, aesthetic, elite, creative projects and tasks, changing the axiological foundations of life. Secondly, in digital life man not only gets new opportunities for creativity, but also faces the threats of his own existence, due to the results of his technicalrationalist activity, which ignores the basic foundations of the human race and offers constructions of a special human world - artificial virtual reality. interpersonal cognition is lost, "there is a complete separation of man from the ground» (K. Jaspers). In the digital space, man is a participant in everything that happens in the techno-united and interconnected world created by globalization. Digitalization is the development, implementation and dissemination of the latest digital technologies in all spheres of modern life in the context of globalization, characterized by the achievements of Google, Amazon, Apple, IMB, Microsoft, Facebook in the US, Alibaba and Tencent in China. Ukraine is actively implementing a digitalization policy. Its implementation will accelerate the processes of digital transformation in Ukraine, increase the level of digital skills and digital competencies in society, increase the competitiveness of employees, increase the level of accessibility to public services for citizens, significantly reduce the risks of hazards when using the Internet. Global problems have united the entire universe in front of the face of the COVID-19 pandemic. The analysis of the scientific literature gives grounds to claim that various most relevant aspects of globalization, its transformation and the role of human in it are reflected in scientific articles and monographs of Ukrainian scientists - V. Lyakh, V. Voronkova, V. Lukianets, O. Kravchenko, L. Oza- 
ISSN 2078-8142 Мультиверсум. Філософський альманах. 2021. Випуск 1(173). Том 1.

dovska , R. Samchuk, V. Pazenyuk, K. Raida and others, as well as the works of Western scholars such as K. Schwab, K. Skinner, E. Giddens, D. Geld and others.

Keywords: globalization, digital human, digital society, digitalization, digital existence, digital accessibility, Internet of Things, artificial intelligence, robotics, divergence. 